Elma, T.A. $\cdot$ E. Suminar $\cdot$ S. Mubarok $\cdot$ A. Nuraini

\title{
Multiplikasi tunas mikro pisang (Musa paradisiaca 1.) 'raja bulu' secara in vitro pada berbagai jenis dan konsentrasi sitokinin
}

\section{Micro shoots of banana (Musa paradisiaca 1.) 'raja bulu' multiplication on different forms and concentrations of cytokinins using in vitro.}

Diterima : 11 Desember 2017/Disetujui : 18 Desember 2017 / Dipublikasikan : 30 Desember 2017

CDepartment of Crop Science, Padjadjaran University

\begin{abstract}
In recent years, the conventional method is used for producing banana seedling. However, it could not supply the demand of banana seedling in enough number and good quality on time. Therefore, the new method to produce banana seedling is required and it could be through by tissue culture method. Tissue culture method couldbe used to produce banana seedling that virus free, uniform and large quantity. The objective of this study was to obtain the best form and concentration of cytokinin on the rate of multiplication of banana buds using in vitro method. The experiment was carried out from November 2016 to March 2017 at Seed Technology and Tissue Culture Laboratory, Faculty of Agriculture, Universitas Padjadjaran in Jatinangor, Sumedang. The experimental design was used in this study and it was Completely Randomized Design (CRD) with thirteen treatments and three replications. Formula of Murashige and Skoog (MS) were used as a base medium in this experiment with a combination of three levels BAP concentrations $\left(1 ; 1,5 ; 2\right.$ and $\left.2,5 \mathrm{mg} \mathrm{L}^{-1}\right)$, three levels of Thidiazuron (TDZ) $\left(0,1 ; 0,3 ; 0,5\right.$ and $\left.0,7 \mathrm{mg} \mathrm{L}^{-1}\right)$ and three levels of Kinetin (1,5; 2; 2,5 and $3 \mathrm{mg} \mathrm{L}^{-}$ 1). The result showed that TDZ $0,1 \mathrm{mg} \mathrm{L}^{-1}$ could increase the number of banana 'Raja Bulu' shoots. It indicated that TDZ $0,1 \mathrm{mg} \mathrm{L}^{-1}$ was the potential cytokinin for shoots multiplication process in banana 'Raja Bulu' by in vitro.
\end{abstract}

Keywords : BAP, In Vitro, Kinetin, Musa paradisiaca L., TDZ

\footnotetext{
Dikomunikasikan oleh Fiky Yulianto Wicaksono Elma T.A. ${ }^{1} \cdot$ E. Suminar ${ }^{2} \cdot$ S. Mubarok ${ }^{2} \cdot$ Anne Nuraini $^{2}$ ${ }^{1}$ Mahasiswa Program Studi Agroteknologi, Fakultas Pertanian, Universitas Padjadjaran

${ }^{2}$ Dosen Fakultas Pertanian, Universitas Padjadjaran

Jl. Raya Jatinangor Km. 21 Jatinangor, Sumedang 45363

Korespondensi : erni.suminar@unpad.ac.id
}

Sari Terbatasnya ketersediaan bibit pisang bermutu di Indonesia disebabkan oleh masih rendahnya jumlah dan kualitas bibit pisang yang dihasilkan melalui metode konvensional. Waktu yang dibutuhkan untuk mendapatkan bibit cukup lama, oleh karena itu digunakan suatu metode perbanyakan untuk menghasilkan bibit dalam waktu yang relatif singkat melalui metode kultur jaringan. Tujuan dari penelitian ini adalah untuk mendapatkan salah satu jenis dan konsentrasi sitokinin terbaik dalam meningkatkan laju multiplikasi tunas pisang raja bulu secara in vitro. Percobaan dilaksanakan dari bulan November 2016 sampai bulan Maret 2017 di Laboratorium Kultur Jaringan dan Teknologi Benih Fakultas Pertanian Universitas Padjadjaran di Jatinangor, Sumedang. Rancangan Acak Lengkap (RAL) digunakan dalam penelitian ini dengan 13 perlakuan, 3 ulangan dan 2 sampel. Media Murashige and Skoog (MS) digunakan sebagai media dasar dengan kombinasi konsentrasi $\operatorname{BAP}\left(1 ; 1,5 ; 2\right.$ and $\left.2,5 \mathrm{mg} \mathrm{L}^{-1}\right)$, Thidiazuron (TDZ) $\left(0,1 ; 0,3 ; 0,5\right.$ and $\left.0,7 \mathrm{mg} \mathrm{L}^{-1}\right)$ and Kinetin $\left(1,5 ; 2 ; 2,5\right.$ and $\left.3 \mathrm{mg} \mathrm{L}^{-1}\right)$ Hasil penelitian menunjukkan bahwa TDZ 0,1 $\mathrm{mg} \mathrm{L}^{-1}$ mampu meningkatkan jumlah tunas pisang 'Raja Bulu', oleh karena itu menunjukkan bahwa TDZ 0,1 $\mathrm{mg} \mathrm{L}^{-1}$ merupakan jenis sitokinin yang potensial untuk proses multiplikasi tunas pada pisang 'Raja Bulu' secara in vitro.

Kata Kunci : BAP, In Vitro, Kinetin, Musa paradisiaca L., TDZ

\section{Pendahuuan}

Tanaman pisang (Musa sp.) merupakan salah satu tanaman buah tropis yang banyak dibudidayakan di Indonesia. Salah satu jenis pisang yang memiliki nilai ekonomis tinggi 
untuk dikembangkan di Indonesia yaitu pisang raja bulu. Pisang raja bulu berasal dari Desa Cibeureum, Kecamatan Cisarua, Kabupaten Bogor, Provinsi Jawa Barat. Nilai indeks glikemiks buah pisang raja bulu sebesar 54\% dibandingkan dengan standar gula sebesar $100 \%$ sehingga baik untuk dikonsumsi oleh penderita diabetes (Pusat Kajian Buah-buahan Tropika, 2005). Produksi pisang mewakili $40-45 \%$ dari total produksi buah nasional (Purwadaria, 2006). Menurut Kementerian Pertanian dalam BPSP (2015), produksi buah pisang di Indonesia dari tahun 2010 sampai 2013 yaitu 5.755.073 ton, 6.132.695 ton, 6.189.043 ton, dan 6.279.279 ton.

Produktivitas pisang yang tidak menentu hasilnya menyebabkan fluktuasi pada nilai ekspor dan impor pisang. Tingginya nilai ekspor pisang Indonesia ke negara-negara importir pisang menjadikan pisang sebagai salah satu jenis buah yang memiliki potensi cukup tinggi untuk dikembangkan. Tingginya volume ekspor pisang dari Indonesia ke negara-negara importir tidak berarti proses budidaya tanaman pisang di Indonesia tidak mengalami masalah-masalah. Sifat kompleks yang dimiliki tanaman pisang ini menjadi permasalahan yang harus dihadapi oleh para petani pisang konvensional yaitu rendahnya mutu bibit pisang untuk tumbuh karena termasuk dalam tanaman triploidi yaitu tidak bisa menghasilkan biji, perbanyakan/ propagasi yang lambat, dasar genetik yang sempit, waktu generasi yang lama (10-18 bulan) dan memerlukan lahan yang besar $( \pm 6$ $\mathrm{m}^{2} /$ tanaman) (Oritz et al., 1995 dalam UNCTS, 2007), hal tersebut disebabkan masih terbatasnya produsen bibit yang dapat menyediakan bibit pisang bermutu dan menjamin keseragaman dalam jumlah yang banyak dan waktu yang relatif singkat.

Untuk memenuhi target perluasan lahan komersial tanaman pisang, ketersediaan bibit bermutu yang seragam dalam jumlah besar masih sulit diperoleh. Perbanyakan secara konvensional menggunakan makropropagasi dengan penanaman sucker (anakan) langsung di lapangan belum dapat meminimalisir permasalahan tersebut sehingga diperlukan alternatif dengan cara mikropropagasi yang merupakan suatu bentuk aplikasi teknik kultur jaringan dengan tujuan untuk memperbanyak tanaman.

Teknik mikropropagasi yang umumnya diaplikasikan yaitu dengan kultur in vitro. Kultur in vitro merupakan teknik yang dapat digunakan untuk menghasilkan bibit pisang yang bermutu dalam jumlah banyak, seragam dan dalam waktu singkat (Meldia dkk., 1996). Untuk memenuhi permintaan akan ketersediaan bibit pisang raja bulu dalam jumlah besar secara serempak dengan kualitas baik, sehat dan bebas penyakit dapat menggunakan teknik budidaya modern dengan metode kultur jaringan atau secara in vitro atau mikropropagasi. Menurut Mantell et al. (1985), mikropropagasi dilakukan dengan cara memotong jaringan menjadi ukuran yang kecil dan ditanam pada media buatan secara aseptik, sehinga akan didapatkan klon tanaman yang mempunyai sifat genetik yang seragam.

Perbanyakan tanaman secara mikropropagasi ini memiliki potensi yang besar khusunya untuk perbanyakan secara vegetatif pada tanaman yang memiliki nilai ekonomis tinggi (Biondi dan Thorpe, 1981). Arinaitwe et al. (2000), menyatakan bahwa proliferasi tergantung pada tipe sitokinin yang digunakan, konsentrasi dan kultivar pisang. Sitokinin berperan penting dalam pembelahan sel dan morfogenesis (Salisbury dan Ross, 1992). Sitokinin yang paling banyak digunakan pada kultur in vitro adalah kinetin, benziladenin (BA atau BAP), dan zeatin. Sitokinin yang umum dipakai adalah BAP (6-Benzylaminopurine) dan pada multiplikasi pisang BAP merupakan sitokinin yang paling efektif (Damasco dan Barba, 1985; Arinaitwe et al., 2000).

Bhosale et al. (2011) menyatakan bahwa multiplikasi tunas dari beberapa spesies pisang yang berbeda dapat meningkatkan rata-rata jumlah tunas yang dihasilkan pada konsentrasi BAP $7 \mathrm{mg} \mathrm{L}^{-1}$. Sitokinin seperti BAP dan Kinetin dikenal dapat mengurangi dormansi meristem apikal dan dapat menginduksi tunas aksilar serta pembentukan tunas adventif dari eksplan meristematik pisang (Buising et al., 1994), sedangkan pada penggunaan kinetin konsentrasi yang tinggi dapat meningkatkan proliferasi tanaman pisang dan pada konsentrasi yang rendah tunas tumbuh pada dasar daun serta tidak adanya tunas adventif..

Pada penelitian yang dilakukan oleh Arinaitwe et al. (2000), menunjukkan bahwa respon kultivar pisang terhadap BAP sangat signifikan dibandingkan dengan jenis sitokinin lainnya seperti Zeatin, Kinetin dan 2-iP, namun pada konsentrasi yang rendah Thidiazuron dapat meningkatkan jumlah tunas pada pisang kultvar 'Ndiziwemiti'. Aplikasi pemberian TDZ yang dilakukan oleh Lee (2001) dalam perbanyakan 
tunas adventif kultivar pisang dengan konsentrasi TDZ 0,01-9,1 $\mu \mathrm{M}\left(0,0022-2,004 \mathrm{mg} \mathrm{L}^{-}\right.$ 1) dihasilkan bahwa pada konsentrasi $0,91 \mu \mathrm{M}$ $\left(0,2 \mathrm{mg} \mathrm{\textrm {L } ^ { - 1 } )}\right.$ menghasilkan jumlah tunas terbanyak, tetapi pada konsentrasi yang lebih tinggi yaitu pada konsentrasi 9,1 $\mu \mathrm{M}\left(2 \mathrm{mg} \mathrm{L}^{-1}\right)$ perkembangan dan perpanjangan tunas terhambat.

\section{Bahan dan Metode}

Percobaan dilaksanakan di Laboratorium Kultur Jaringan Teknologi Benih, Fakultas Pertanian, Universitas Padjadjaran, Jatinangor. Waktu pelaksanaan percobaan ini dimulai dari Bulan November 2016 sampai Bulan Maret 2017.

Sumber bahan tanam yang digunakan berupa tunas hasil multiplikasi planlet pisang 'Raja Bulu'. Sumber eksplan atau bahan tanam didapatkan dari koleksi Laboratorium Kultur Jaringan Teknologi Benih Fakultas Pertanian Universitas Padjadjaran yang selanjutnya dilakukan subkultur ke media pertumbuhan tunas mikro yaitu media Murashige \& Skoog (MS) yang telah ditambahkan berbagai konsentrasi serta jenis sitokinin berbeda. Bahan-bahan yang dibutuhkan antara lain plantlet pisang raja bulu, media dasar Murashige \& Skoog (MS), sukrosa, agar-agar, zat pengatur tumbuh yaitu Benzylaminopurine (BAP) Sigma; KinetinMerck; dan Thidiazuron Phyto Technology Laboratories, aquades steril, alkohol 70\%, spiritus, tisu, karet gelang,plastik dan kertas label.

Alat yang digunakan pada tahap persiapan media yaitu timbangan analitik, beaker glass, pipet, hot plate, magnetic stirrer, $\mathrm{pH}$ meter, botol kultur, autoclave, gelas ukur, oven, alat suntik 2 $\mathrm{ml}$, lemari pendingin. Pada tahap penanaman, alat-alat yang digunakan adalah LAF (Laminar Air Flow), petridish, gunting, scalpel, sprayer, dan lampu spiritus. Alat-alat yang digunakan pada tahap pemeliharaan antara lain rak kultur, lampu, termohigrometer, dan alkohol 70\%.

Rancangan percobaan yang digunakan adalah Rancangan Acak Lengkap yang terdiri dari 13 perlakuan, setiap perlakuan terdiri dari 3 ulangan dan setiap ulangan terdiri dari 2 sampel percobaan yang berisi satu eksplan, sehingga jumlah sampel percobaan ada 78 sampel percobaan. Semua perlakuan menggunakan media dasar Murashige \& Skoog (MS) dengan penambahan berbagai jenis dan konsentrasi sitokinin sebagai berikut : $\mathrm{A}=$ Tanpa
Penambahan Sitokinin (Kontrol); B = Benzylaminopurine $1 \mathrm{mgL}^{-1} ; \mathrm{C}=$ Benzylaminopurine 1.5 $\mathrm{mgL}^{-1} ; \mathrm{D}=$ Benzylaminopurine $2 \mathrm{mgL}^{-1} ; \mathrm{E}=$ Benzylaminopurine $2.5 \mathrm{mgL}^{-1} ; \mathrm{F}=$ Thidiazuron 0.1 $\mathrm{mgL}^{-1} ; \mathrm{G}=$ Thidiazuron $0.3 \mathrm{mgL}^{-1} ; \mathrm{H}=$ Thidiazuron $0.5 \mathrm{mgL}^{-1} ; \mathrm{I}=$ Thidiazuron $0.7 \mathrm{mgL}^{-}$ 1; J = Kinetin $1.5 \mathrm{mgL}^{-1} ; \mathrm{K}=$ Kinetin $2 \mathrm{mgL}^{-1} ; \mathrm{L}=$ Kinetin $2.5 \mathrm{mgL}^{-1}$; $\mathrm{M}=$ Kinetin $3 \mathrm{mgL}^{-1}$.

Data hasil percobaan pada parameter utama dianalisis menggunakan analisis ragam berdasarkan uji F taraf 5\%. Apabila terdapat beda nyata dilanjutkan dengan Uji DMRT pada taraf 5\%. Pengamatan paramater utama dilakukan terhadap peubah diantaranya : persentase eksplan bertunas; jumlah tunas, jumlah tunas, panjang tunas, jumlah daun, dan persentase eksplan berakar .

\section{Hasil dan Pembahasan}

Persentase Eksplan Bertunas. Pengamatan eksplan bertunas dilakukan pada 4 MST, 8 MST, dan 12 MST setelah eksplan ditanam pada media regenerasi. Pengamatan ini bertujuan untuk mengetahui tingkat multiplikasi yang menghasilkan calon tunas mikro yang maksimal. Persentase eksplan bertunas pada setiap media perlakuan memiliki kemampuan menghasilkan tunas yang berbeda. Respon eksplan yang dihasilkan terhadap media ditandai dengan pembengkakan eksplan hingga akhirnya menghasilkan pembentukan tunas. Berdasarkan Tabel 1. terlihat bahwa peng-gunaan berbagai jenis sitokinin memberikan pengaruh yang berbeda nyata terhadap persentase eksplan bertunas pada umur 4 MST dan 12 MST.

Setiap perlakuan memberikan respon yang berbeda terhadap pertumbuhan tunas pada eksplan yang ditanam. Perlakuan yang memberikan respon terbaik terhadap persentase eksplan bertunas adalah perlakuan B (Benzylaminopurine $1 \mathrm{mg} \mathrm{L}^{-1}$ ), C (Benzylaminopurine 1,5 $\mathrm{mg} \mathrm{L} \mathrm{L}^{-1}$ ), D (Benzylaminopurine $\left.2 \mathrm{mg} \mathrm{L}^{-1}\right), \mathrm{E}$ (Benzylaminopurine 2,5 $\mathrm{mg} \mathrm{L}^{-1}$ ) dan $\mathrm{F}$ (Thidiazuron 0,1 mg L-1) yaitu 50\% eksplan bertunas pada 12 MST. Kemampuan eksplan bertunas dipengaruhi oleh beberapa faktor salah satunya genotip tanaman, dalam meningkatkan multiplikasi tunas (proliferasi) juga dipengaruhi oleh jenis sitokinin dan konsentrasi yang digunakan (Strosse et al., 2004).

Rata-rata persentase tunas yang tumbuh terlihat bahwa perlakuan media E (Benzyl- 
aminopurine $\left.2,5 \mathrm{mg} \mathrm{L}^{-1}\right)$ memiliki tingkat pembentukan tunas relatif lebih tinggi $(66,67 \%$, $50,00 \%$ dan $50,00 \%$ ) pada umur 4,8 dan 12 MST jika dibandingkan dengan perlakuan media lainnya. Pada perlakuan E (Benzylaminopurine 2,5 $\mathrm{mg} \mathrm{L}^{-1}$ ) dengan konsentrasi yang rendah eksplan memliki kemampuan membentuk tunas lebih tinggi, sedangkan persentase eksplan bertunas relatif rendah terdapat pada perlakuan M (Kinetin $3 \mathrm{mg} \mathrm{L}^{-1}$ ) yaitu $0,00 \%$ pada 4,8 dan 12 MST.

Tabel 1. Kemampuan Eksplan Bertunas (\%) pada Berbagai Media Perlakuan pada Umur 4, 8 dan 12 MST.

\begin{tabular}{lccc}
\hline \multirow{2}{*}{ Perlakuan } & \multicolumn{3}{c}{ Presentase Eksplan Bertunas (\%) } \\
\cline { 2 - 4 } & $\mathbf{4}$ MST & 8 MST & 12 MST \\
\hline $\mathrm{A}$ & $16,67 \mathrm{ab}$ & $16,67 \mathrm{a}$ & $16,67 \mathrm{ab}$ \\
$\mathrm{B}$ & $33,33 \mathrm{ab}$ & $33,33 \mathrm{a}$ & $50,00 \mathrm{~b}$ \\
$\mathrm{C}$ & $33,33 \mathrm{ab}$ & $33,33 \mathrm{a}$ & $50,00 \mathrm{~b}$ \\
$\mathrm{D}$ & $50,00 \mathrm{ab}$ & $50,00 \mathrm{a}$ & $50,00 \mathrm{~b}$ \\
$\mathrm{E}$ & $66,67 \mathrm{~b}$ & $50,00 \mathrm{a}$ & $50,00 \mathrm{~b}$ \\
$\mathrm{~F}$ & $50,00 \mathrm{ab}$ & $50,00 \mathrm{a}$ & $50,00 \mathrm{~b}$ \\
$\mathrm{G}$ & $16,67 \mathrm{ab}$ & $16,67 \mathrm{a}$ & $33,33 \mathrm{ab}$ \\
$\mathrm{H}$ & $16,67 \mathrm{ab}$ & $33,33 \mathrm{a}$ & $33,33 \mathrm{ab}$ \\
$\mathrm{I}$ & $0,00 \mathrm{a}$ & $16,67 \mathrm{a}$ & $16,67 \mathrm{ab}$ \\
$\mathrm{J}$ & $0,00 \mathrm{a}$ & $0,00 \mathrm{a}$ & $0,00 \mathrm{a}$ \\
$\mathrm{K}$ & $0,00 \mathrm{a}$ & $16,67 \mathrm{a}$ & $16,67 \mathrm{ab}$ \\
$\mathrm{L}$ & $16,67 \mathrm{ab}$ & $16,67 \mathrm{a}$ & $16,67 \mathrm{ab}$ \\
$\mathrm{M}$ & $0,00 \mathrm{a}$ & $0,00 \mathrm{a}$ & $0,00 \mathrm{a}$ \\
\hline
\end{tabular}

Keterangan : Nilai rata-rata yang diikuti oleh huruf yang sama tidak berbeda nyata menurut Uji Duncan pada taraf $5 \%$.

MST = Minggu Setelah Tanam.

Menurut George et al. (2008), pemberian sitokinin dengan konsentrasi rendah dapat memberikan respon pertumbuhan tunas aksilar maupun tunas adventif karena kandungan sitokinin endogen sudah mencukupi, sedangkan pada pengaruh konsentrasi sitokinin yang tinggi mengalami persentase eksplan bertunas yang cenderung rendah serta dapat menghambat pemanjangan jaringan meristem dan pembentukan tanaman baru (plantlet), selain itu Ngomuo et al. (2013), menyatakan rendahnya pertumbuhan eksplan membentuk tunas diduga karena eksplan sangat bergantung dengan faktor endogen eksplan itu sendiri, selain itu terjadi peranan zat pengatur tumbuh bila kondisi fisiologis eksplan dalam kondisi yang baik untuk tumbuh.

Jumlah Tunas Mikro. Data pengamatan pengaruh perlakuan penggunaan jenis sitokinin yang berbeda terhadap jumlah tunas mikro pada umur 4, 8, dan 12 MST. Berdasarkan data hasil analisis ragam menunjukkan pengaruh yang berbeda nyata dari perlakuan $\mathrm{F}$ (Thidiazuron 0,1 $\mathrm{mg} \mathrm{L}^{-1}$ ) terhadap perlakuan $\mathrm{J}$ (Kinetin 1,5 $\mathrm{mg} \mathrm{L}^{-1}$ ) dan $\mathrm{M}$ (Kinetin $3 \mathrm{mg} \mathrm{L}^{-1}$ ) pada umur12 MST terhadap jumlah tunas seperti yang terlihat pada Tabel 2.

Tabel 2. Pengaruh Berbagai Media Perlakuan pada Umur 4, 8 dan 12 MST terhadap Jumlah Tunas (buah).

\begin{tabular}{lccc}
\hline Perlakuan & \multicolumn{3}{c}{ Jumlah Tunas (buah) } \\
\hline A & 4 MST & 8 MS & 12 MST \\
\hline B & $0,33 \mathrm{ab}$ & $0,33 \mathrm{ab}$ & $0,33 \mathrm{a}$ \\
$\mathrm{C}$ & $0,67 \mathrm{ab}$ & $1,00 \mathrm{abc}$ & $1,00 \mathrm{ab}$ \\
$\mathrm{D}$ & $0,67 \mathrm{ab}$ & $0,67 \mathrm{abc}$ & $1,00 \mathrm{ab}$ \\
$\mathrm{E}$ & $1,00 \mathrm{ab}$ & $1,00 \mathrm{abc}$ & $1,00 \mathrm{ab}$ \\
$\mathrm{F}$ & $1,33 \mathrm{~b}$ & $1,33 \mathrm{bc}$ & $1,67 \mathrm{bc}$ \\
$\mathrm{G}$ & $1,00 \mathrm{ab}$ & $1,67 \mathrm{~b}$ & $2,33 \mathrm{c}$ \\
$\mathrm{H}$ & $0,33 \mathrm{ab}$ & $0,33 \mathrm{ab}$ & $0,67 \mathrm{a}$ \\
$\mathrm{I}$ & $0,33 \mathrm{ab}$ & $0,67 \mathrm{abc}$ & $0,67 \mathrm{a}$ \\
$\mathrm{J}$ & $0,00 \mathrm{a}$ & $0,33 \mathrm{ab}$ & $0,33 \mathrm{a}$ \\
K & $0,00 \mathrm{a}$ & $0,00 \mathrm{a}$ & $0,00 \mathrm{a}$ \\
$\mathrm{L}$ & $0,00 \mathrm{a}$ & $0,33 \mathrm{ab}$ & $0,33 \mathrm{a}$ \\
M & $0,33 \mathrm{ab}$ & $0,33 \mathrm{ab}$ & $0,33 \mathrm{a}$ \\
\hline
\end{tabular}

Keterangan : Nilai rata-rata yang diikuti oleh huruf yang sama tidak berbeda nyata menurut Uji Duncan pada taraf $5 \%$.

MST $=$ Minggu Setelah Tanam.

Jumlah tunas pada berbagai perlakuan berbeda nyata pada umur 4, 8 dan 12 MST (Tabel 2). Pada 4 MST, rata-rata jumlah tunas pada perlakuan BAP $2,5 \mathrm{mg} \mathrm{L}^{-1}$ (E) memiliki jumlah tunas yang relatif lebih banyak, namun pada 12 MST jumlah tunas relatif lebih banyak dihasilkan pada perlakuan Thidiazuron $0,1 \mathrm{mg}$ $\mathrm{L}^{-1}(\mathrm{~F})$, sedangkan perlakuan J (Kinetin 1,5 mg L1) dan $\mathrm{M}$ (Kinetin $3 \mathrm{mg} \mathrm{L}^{-1}$ ) tidak memiliki tunas sama sekali. Perlakuan Thidiazuron $0,1 \mathrm{mg} \mathrm{L}^{-1}$ (F) pada umur 12 MST mengalami peningkatan jumlah tunas, berbeda dengan perlakuan BAP 2 $\mathrm{mg} \mathrm{L}^{-1}$ (D) tidak mengalami peningkatan terhadap jumlah tunas, hal ini diduga karena pada umur $12 \mathrm{MST}$, pertumbuhan peningkatan jumlah tunas terhenti pada perlakuan tersebut.

Jumlah tunas yang berbeda-beda dipengaruhi oleh kemampuan eksplan dalam menyerap unsur hara yang ada di dalam media MS dan zat pengatur tumbuh yang diberikan (Gambar 1.). Menurut George et al. (2008), aplikasi pemberian sitokinin tunggal mampu menghasilkan tunas yang maksimal, namun pada konsentrasi tertentu akan menghasilkan kelainan pada tunas yang diperoleh. 

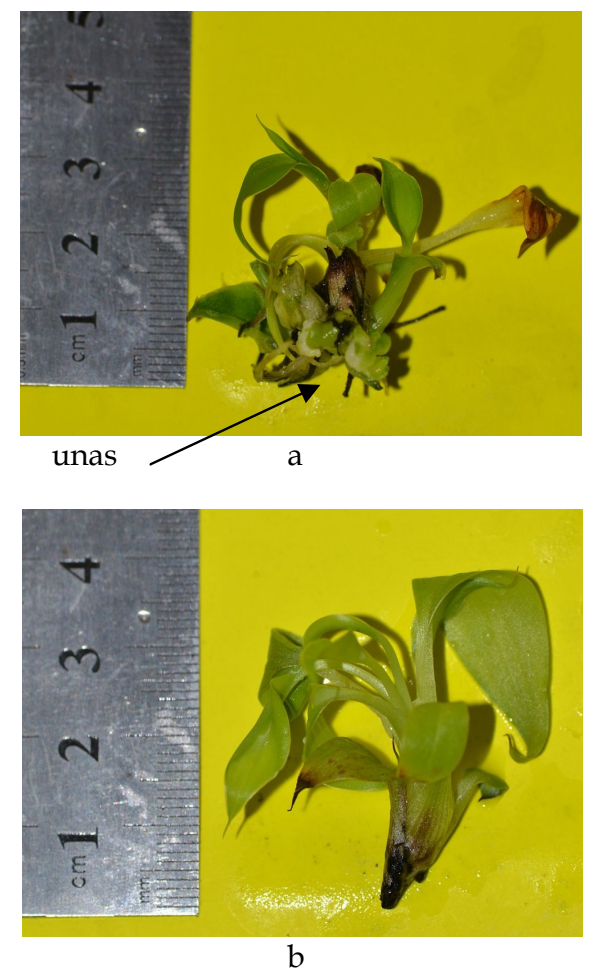

\section{Gambar 1. Perbedaan Eksplan dalam Kemampuan Menghasilkan Tunas a. Menghasilkan tunas \\ b. Tidak menghasilkan tunas baru}

Thidiazuron memiliki efektifitas yang tinggi dalam regenerasi tanaman (Srangsam \& Kanchanapoom, 2003) dan TDZ akan stabil dan lebih aktif pada konsentrasi rendah daripada adenine dan purin (jenis sitokinin) lainnya (Mok et al. 1987). Hal ini karena aktivitas sitokinin yang terkait dengan proses pertumbuhan dan perkembangan dalam siklus sel di dalam proses metabolisme asam nukleat dan sintesis protein (Adds et al., 2004).

Tinggi Tunas. Tinggi tunas merupakan parameter pengamatan yang cukup penting untuk melihat kemampuan eksplan dalam proses pertumbuhannya.

Data pengamatan pengaruh media perlakuan terhadap tinggi tunas diamati pada umur 4, 8 dan 12 MST. Hasil analisis ragam menunjukkan adanya pengaruh yang berbeda nyata dari media perlakuan terhadap tinggi tunas pada umur 4, 8 dan 12 MST. Perlakuan Kontrol (A) memberikan pengaruh yang lebih baik terhadap tinggi tunas daripada perlakuan yang lainnya.

Perlakuan Kontrol (A) atau Kontrol, yaitu tanpa penambahan jenis dan konsentrasi sitokinin pada media perlakuan memberikan pertumbuhan yang lebih tinggi pada tinggi tunas, jika dibandingkan perlakuan lain pada umur 4, 8 dan 12 MST. Tinggi tunas diduga dipengaruhi oleh jumlah tunas yang muncul, sehingga semakin sedikit tunas yang muncul, maka ukuran tingginya semakin meningkat, dan sebaliknya. Hal ini karena energi yang dibutuhkan untuk pemanjangan tunas digunakan untuk pembentukan calon tunas lainnya, sehingga tinggi tunas dapat mengalami penghambatan. Menurut Lu (2005), sitokinin akan memacu pembelahan sel dan menghambat elongasi (perpanjangan), sehingga yang banyak terbentuk adalah tunas, sedangkan elongasi tunasnya dihambat. Perlakuan yang memberikan respon pertumbuhan tinggi tunas yang relatif rendah terdapat pada perlakuan Thidiazuron $0,5 \mathrm{mg} \mathrm{L}^{-1}$ $(\mathrm{H})$. Proses proliferasi tunas dan perpanjangan dipengaruhi oleh sitokinin dan konsentrasi yang digunakan (Strosse et al., 2004).

Tabel 3. Pengaruh berbagai Jenis dan Konsentrasi Sitokinin terhadap Tinggi Tunas pada Umur 4, 8 dan 12 MST.

\begin{tabular}{llcl}
\hline \multirow{2}{*}{ Perlakuan } & \multicolumn{3}{c}{ Tinggi Tunas (cm) } \\
\cline { 2 - 4 } & $\mathbf{4 ~ M S T}$ & $\mathbf{8 ~ M S T}$ & $\mathbf{1 2}$ MST \\
\hline $\mathrm{A}$ & $3,88 \mathrm{~b}$ & $6,03 \mathrm{~d}$ & $7,48 \mathrm{f}$ \\
$\mathrm{B}$ & $3,53 \mathrm{ab}$ & $4,50 \mathrm{bcd}$ & $4,98 \mathrm{bcde}$ \\
$\mathrm{C}$ & $3,68 \mathrm{ab}$ & $3,65 \mathrm{abc}$ & $4,82 \mathrm{bcde}$ \\
$\mathrm{D}$ & $2,25 \mathrm{a}$ & $2,98 \mathrm{ab}$ & $3,67 \mathrm{ab}$ \\
$\mathrm{E}$ & $3,78 \mathrm{ab}$ & $4,38 \mathrm{bcd}$ & $4,38 \mathrm{abc}$ \\
$\mathrm{F}$ & $2,60 \mathrm{ab}$ & $3,73 \mathrm{abc}$ & $4,70 \mathrm{abcd}$ \\
$\mathrm{G}$ & $2,55 \mathrm{ab}$ & $3,48 \mathrm{abc}$ & $4,27 \mathrm{abc}$ \\
$\mathrm{H}$ & $2,30 \mathrm{a}$ & $2,55 \mathrm{a}$ & $2,82 \mathrm{a}$ \\
$\mathrm{I}$ & $2,90 \mathrm{ab}$ & $3,50 \mathrm{a}$ & $3,90 \mathrm{abc}$ \\
$\mathrm{J}$ & $3,30 \mathrm{ab}$ & $5,10 \mathrm{~cd}$ & $6,70 \mathrm{ef}$ \\
$\mathrm{K}$ & $3,05 \mathrm{ab}$ & $4,18 \mathrm{abcd}$ & $5,92 \mathrm{cdef}$ \\
$\mathrm{L}$ & $3,38 \mathrm{ab}$ & $4,93 \mathrm{~cd}$ & $6,42 \mathrm{def}$ \\
$\mathrm{M}$ & $3,10 \mathrm{ab}$ & $5,10 \mathrm{~cd}$ & $5,63 \mathrm{bcdef}$ \\
\hline Kete
\end{tabular}

Keterangan : Nilai rata-rata yang diikuti oleh huruf yang sama tidak berbeda nyata menurut Uji Duncan pada taraf $5 \%$.

MST $=$ Minggu Setelah Tanam.

Jumlah Daun. Pengamatan jumlah daun dilakukan pada umur 4, 8 dan 12 MST dengan menghitung jumlah daun pada setiap eksplan yang menghasilkan daun (Tabel 4).

Data rata-rata pengamatan jumlah daun pada umur 4, 8 dan 12 MST dapat dilihat pada Tabel 4. Berdasarkan hasil analisis ragam, berbagai media perlakuan pada jumlah daun memberikan pengaruh yang berbeda nyata pada umur 8 dan 12 MST. Hal ini diduga karena pembentukkan daun dipengaruhi jumlah tunas 
yang diperoleh. Pada pengamatan jumlah tunas (Tabel 2.), menunjukkan bahwa semakin sedikit jumlah tunas yang terbentuk, maka dapat menghasilkan jumlah daun yang lebih banyak, contohnya pada perlakuan K (Kinetin $2 \mathrm{mg} \mathrm{L}^{-1}$ ) yang menghasilkan rata-rata 0,33 tunas sampai umur 12 MST dan menghasilkan jumlah daun yang cukup banyak dengan rata-rata adalah 5,33 helai daun (Tabel 4.) Menurut Demissie (2013), jumlah daun dipengaruhi oleh jumlah tunas yang muncul, sehingga semakin sedikit tunas yang muncul, maka jumlah daun yang terbentuk akan semakin banyak dan sebaliknya.

Tabel 4. Pengaruh Berbagai Jenis dan Konsentrasi Sitokinin terhadap Jumlah Daun pada Umur 4, 8 dan 12 MST

\begin{tabular}{ccll}
\hline \multirow{2}{*}{ Perlakuan } & \multicolumn{3}{c}{ Jumlah Daun (helai) } \\
\cline { 2 - 4 } & 4 MST & 8 MST & 12 MST \\
\hline $\mathrm{A}$ & $1,00 \mathrm{a}$ & $1,50 \mathrm{ab}$ & $3,67 \mathrm{~cd}$ \\
$\mathrm{~B}$ & $1,50 \mathrm{a}$ & $1,83 \mathrm{ab}$ & $4,00 \mathrm{de}$ \\
$\mathrm{C}$ & $1,33 \mathrm{a}$ & $2,17 \mathrm{ab}$ & $3,50 \mathrm{bcd}$ \\
$\mathrm{D}$ & $1,33 \mathrm{a}$ & $1,67 \mathrm{a}$ & $2,83 \mathrm{abc}$ \\
$\mathrm{E}$ & $1,00 \mathrm{a}$ & $1,67 \mathrm{a}$ & $3,33 \mathrm{abcd}$ \\
$\mathrm{F}$ & $1,67 \mathrm{a}$ & $2,00 \mathrm{a}$ & $2,67 \mathrm{ab}$ \\
$\mathrm{G}$ & $1,17 \mathrm{a}$ & $2,50 \mathrm{ab}$ & $2,83 \mathrm{abc}$ \\
$\mathrm{H}$ & $1,17 \mathrm{a}$ & $1,67 \mathrm{a}$ & $2,67 \mathrm{ab}$ \\
$\mathrm{I}$ & $1,50 \mathrm{a}$ & $2,17 \mathrm{ab}$ & $2,50 \mathrm{a}$ \\
$\mathrm{J}$ & $1,50 \mathrm{a}$ & $2,33 \mathrm{ab}$ & $4,67 \mathrm{ef}$ \\
$\mathrm{K}$ & $1,33 \mathrm{a}$ & $3,00 \mathrm{~b}$ & $5,33 \mathrm{f}$ \\
$\mathrm{L}$ & $1,50 \mathrm{a}$ & $2,33 \mathrm{ab}$ & $4,83 \mathrm{ef}$ \\
M & $1,67 \mathrm{a}$ & $2,33 \mathrm{ab}$ & $4,67 \mathrm{ef}$ \\
\hline
\end{tabular}

Keterangan : Nilai rata-rata yang diikuti oleh huruf yang sama tidak berbeda nyata menurut Uji Duncan pada taraf $5 \%$.

MST $=$ Minggu Setelah Tanam.

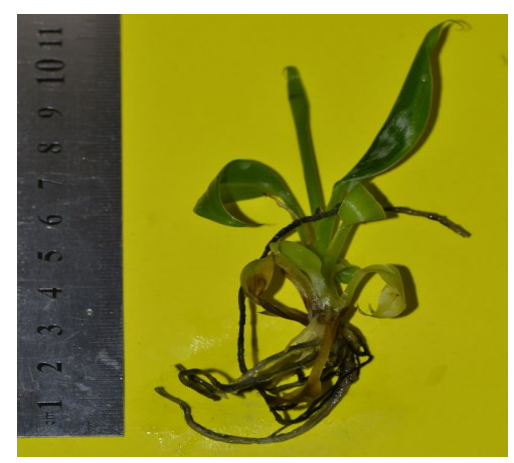

Gambar 3. Eksplan dengan Rata-rata Jumlah Daun Tertinggi pada Perlakuan K (Kinetin 2 mg $\left.L^{-1}\right)$.

Ditinjau dari rata-rata jumlah daun pada eksplan dalam setiap media perlakuan, terdapat kecenderungan media perlakuan yang memiliki jumlah daun relatif lebih banyak pada perlakuan $\mathrm{K}$ (Kinetin $2 \mathrm{mg} \mathrm{L}^{-1}$ ), jika dibandingkan dengan media perlakuan lainnya, sedangkan perlakuan yang menghasilkan jumlah daun relatif lebih rendah yaitu perlakuan I (Thidiazuron $0,7 \mathrm{mg} \mathrm{L-}$ 1). Penggunaan Thidiazuron pada konsentrasi tinggi dapat menurunkan jumlah tunas yang menyebabkan penurunan jumlah daun (Farhani et al. 2008).

\section{Daftar Pustaka}

Arinaitwe, G., P.R. Rubaihayo, and M.J.S. Magambo. 2000. Proliferation rate effects of cytokinins on banana (Musa spp.) cultivars. Sci. Hortic. 86:13-21.

Badan Pusat Statistika Pertanian (BPSP). 2015. Data Hortikultura : Kementrian Pertanian. Tersedia online di http://aplikasi. pertanian.go.id/bdsp/hasil_kom.asp

Bhosale, U., S. Dubhashi, N. Mali and H. Rathod. 2011. In vitro shoot multiplication in different species of banana. Asian J. Plant Sci. and Res, 1 (3): 23-27.

Biondi, S. and T.A. Thorpe. 1981. Plant Tissue Culture Methods and Application in Agriculture. Academic Pres, Inc., New York.

Buising, C. M., R. C. Shoemaker, and R. M. Benbow. 1994. Early events of multiple bud formation and shoot development in soybean embryonic axes treatedwith the cytokinin, 6-benzylaminopurine. Am. J. Bot. 81(1): 1435-1448. Availabe on online at http://dx.doi.org/10.2307/2445317.

Damasco, D.P., and R.C. Barba. 1985. In vitro culture of Saba banana [Musa balbisianacv Saba (BBB)]. In: Biotechnology in International Agricultural Research. Proceeding of the Inter Center Seminar on International Agricultural Research Center (IARCs) and Biotechnology. Manila, Philippines 23-27 April 1984. Manila, Philippines pp.41-44

Farhani, F., H. Aminpoor, M. Sheidai, Z. Noormohammadi, and M.H. Mazinani. 2008. An improved system for in vitro propagation of banana (Musa acuminate L.) cultivars. Asian Journal of Plant Science 7(1): 116-118.

George, E.F., M. A. Hall, and G.J.D. Clerk. 2008. Plant Propagation by Tissue Culture 3rd Edition. Springer, Netherlands. pp. 175-78.

Lee, S.W. 2001. Thidiazuron in The Improve-ment of Banana Micropropagation. The Second 
International Symposium on Biotechnology of Tropical and Subtropical Species. Taipei, Taiwan, Rep. of China. pp. 1-11.

Mantell, S.H., J.A. Mattews and R.A. McKee. 1985. Principles of Plant Biotechnology; An Introduction to Genetic Enginering in Plant. Blackwell Scientific Pub. London

Meldia, Y.S., A. Sunyoto, dan Suprianto. 1996. Pembibitan tanaman pisang. Solok: Balai Penelitian Tanaman Buah.

Mok, M.C., D.W.S. Mok, J.E. Turner, and C.V Mujer. 1987. Biological and biochemical effect of cytokinin - active phenylurea derivatives in tissue culture systems. Hort. Science 22:1194-97.

Ngomuo, M., E. Mneney, and P. Ndakidemi. 2013. The effect of auxins and cytokinin on growth and development of (Musa sp.) var. "Yangambi" explanted in tissue culture. American J. Plant Sciences 4 : 2174-2180.
Purwadaria, H.K. 2006. Issues and solutions of fresh fruits export in Indonesia. Department of Agricultural Engineering, Bogor Agricultural University. Indonesia.

Srangsam A., K. Kanchanapoom. 2003. Thidiazuron induced plant regeneration in callus culture of triploid banana (Musa sp.) 'Gros Michel', AAA group. Songklanakarin J. Sci. Technol Vol. 25 (6) : 689-696.

Strosse, H., I. Van den Houwe, and B. Panis. 2004. Banana cell and tissue culture: cellular, molecular biology and induced mutations. Polymouth, U.K.: Science Publishers Inc, pp : 1-12.

Uganda National Council for Science and Technology (UNCTS). 2007. The Biology of Bananas and Plantains. Uganda National Council for Science and Technology (UNCTS) with Program for Biosafety System (PBS). 